PERM JOURNAL OF PETROLEUM AND MINING ENGINEERING

ВЕСТНИК ПНИПУ. ГЕОЛОГИЯ. НЕФТЕГАЗОВОЕ И ГОРНОЕ ДЕЈО

ISSN 2224-9923

Volume/ TOM 16 №2, 2017

http://vestnik:pstu.ru/geo/

УДК 622.834

Article / Статья

(C) PNRPU / ПНИПУ, 2017

\title{
WORK EXPERIENCE ON AUTOMATION OF PROCESSING OF SURVEY MEASUREMENTS OF BACKFILL OF MINES OF URALKALI PJSC
}

\author{
Sergei N. Kutovoi, Anatolii V. Kataev, Denis A. Vasenin, Evgenii M. Efimov
}

Perm National Research Polytechnic University (29 Komsomolskii av., Perm, 614990, Russian Federation)

\section{ОПЫТ РАБОТ ПО АВТОМАТИЗАЦИИ ОБРАБОТКИ МАРКШЕЙДЕРСКИХ ЗАМЕРОВ ЗАКЛАДКИ ВЫРАБОТАННОГО ПРОСТРАНСТВА НА РУДНИКАХ ПАО УРАЛКАЛИЙ» \\ С.Н. Кутовой, А.В. Катаев, Д.А. Васенин, Е.М. Ефимов}

Пермский национальный исследовательский политехнический университет (614990, Россия, г. Пермь, Комсомольский пр., 29)

Received / Получена: 21.03.2017. Accepted / Принята: 15.05.2017. Published / Опубликована: 30.06.2017

\section{Key words:}

program module, backfill

of mines, mine survey

service, protection of completing

objects, mining and geological

information system, field

of potassium salts.

\begin{abstract}
During the last years of development of Verkhnekamsk potassium salt field (VKPSF) activities that aimed to prevent harmful impact of underground mines on earth's surface and industrial, civil and natural objects located on it and water breakthrough into mines became relevant. One of the main methods to control these phenomena is to backfill empty space with solid wastes of potassium ore processing.

Growing volume of backfill works leads to an increase in survey service of mining enterprises, which does instrumental control over fulfillment of design parameters of backfilling mines. In this regard, there are questions raised on automation of processing of results of instrumental measurements of backfill volumes and compiling graphic and text reporting documentation.

In order to solve this problem the authors of the article developed a software module that allows to solve in automated mode most of the tasks that are faced by staff of survey departments of VKPSF mines who monitor compliance with design parameters of volume of backfilling operations.

The article provides information on functional possibilities and technical architecture of a software module. Examples of interface solutions and information on volumes of reporting documents being created are given.

A developed software module is integrated into created mining and geological information system of Uralkali PJSC. A system is created with direct participation of the authors and provides 21 automated workplaces for various mining specialists (miners, geologists, mine surveyors, geophysicists, geomechanics, environmentalists etc.) starting from the primary link in mines and ending with the management of Uralkali PJSC.
\end{abstract}

В последние годы при отработке Верхнекамского месторождения калийных солей (ВКМКС) все большее значение приобретают мероприятия по предотвращению вредного влияния подземных разработок на земную поверхность и находящихся на ней промышленных, гражданских и природных объектов, а также по недопушению прорыва воды в горные выработки. Один из основных методов борьбы с этими явлениями - закладка выработанного пространства твердыми отходами переработки калийных руд.

Растущие объемы закладочных работ приводят к увеличению нагрузки на маркшейдерскую службу горных предприятий, осушествляюшую инструментальный контроль за выполнением проектных показателей по закладываемым горным выработкам. В связи с этим остро встают вопросы автоматизации обработки результатов инструментальных измерений объемов закладки и составления графической и текстовой отчетной документации.

Для решения данной задачи авторами статьи был разработан программный модуль, позволяющий решать в автоматизированном режиме большинство задач, стоящих перед сотрудниками маркшейдерских отделов рудников ВКМКС, выполняющих функции контроля за соблюдением проектных показателей объемов закладочных работ.

В статье приводится информация по функциональным возможностям и технической архитектуре программного модуля. Даны примеры интерфейсных решений, а также информация по объемам создаваемых отчетных документов.

Разработанный программный модуль полностью интегрирован в создаваемую горно-геологическую информационную систему ПАО «Уралкалий». Данная система создается при непосредственном участии авторов и предусматривает в своем составе 21 автоматизированное рабочее место различных специалистов горного производства (горняки, геологи, маркшейдеры, геофизики, геомеханики, экологи и др.), начиная от первичного звена на рудниках и кончая руководством ПАО «Уралкалий».

Sergei N. Kutovoi - PhD in Technical Sciences, Associate Professor at the Department of Mine Survey, Geodesy and Geoinformation Systems (tel.: +007 3422198427 , e-mail: geotech@pstu.ac.ru). The contact person for correspondence.

Anatolii V. Kataev - PhD in Technical Sciences, Associate Professor at the Department of Mine Survey, Geodesy and Geoinformation Systems, (tel.: +007 3422198427 , e-mail: geotech@pstu.ac.ru).

Denis A. Vasenin - Engineer at the Department of Mine Survey, Geodesy and Geoinformation Systems (tel.: +007 34221984 27, e-mail: geotech@pstu.ac.ru).

Evgenii M. Efimov - Engineer at the Department of Mine Survey, Geodesy and Geoinformation Systems (tel.: +007 342 219 84 27, e-mail: geotech@pstu.ac.ru).

Кутовой Сергей Николаевич - кандидат технических наук, доцент кафедры маркшейдерского дела, геодезии и геоинформационных систем (тел.: +007 3422198427 , e-mail: geotech@pstu.ac.ru). Контактное лицо для переписки.

Катаев Анатолий Вениаминович - кандидат технических наук, доцент кафедры маркшейдерского дела, геодезии и геоинформационных систем (тел.: +007 3422198427, e-mail: geotech@pstu.ac.ru).

Васенин Денис Александрович - инженер кафедры маркшейдерского дела, геодезии и геоинформационных систем (тел.: +007 3422198427 , e-mail: geotech@pstu.ac.ru).

Ефимов Евгений Михайлович - инженер кафедры маркшейдерского дела, геодезии и геоинформационных систем (тел.: +007 3422198427, e-mail: geotech@pstu.ac.ru). 


\section{Introduction}

Backfilling of mines of Verkhnekamsk field have been carried out for more than 70 years. Works are performing mainly to protect mines from flooding and guard surface and underground facilities as well as engineering structures from subsidence.

Important factors that determine necessary and sufficient amounts of backfilling operations are the features of geological structure of the field and parameters of development system for mining operations.

One of the features of geological structure of rocks is no water in salt deposits and fair water content of rocks that host salt deposit. The upper layer of rock salt is a waterproof stratum (WPS), which protects potash mines from flooding. So, keeping it from subsidence is a requirement for mining operations.

Commercial layers of sylvinite $(\mathrm{AB} ; \mathrm{Cr}-2)$ and carnallite (B) salts are processed by a chamber system of development. Preparation of reserves is conducted by a panel (SKRU-1, SKRU-2, BKPRU-2) and panel-block (SKRU-3, BPKRU-4) methods. The need to maintain a waterproof layer in a stable state determines parameters of a development system that ensure stability of interchamber bypassed resources and, consequently, the entire rock massif. Thus, most of balance reserves remain in bypassed areas. The factor recovery of mineral ranges from 0.33 to 0.5 [1]. Increase in recovery of ore at all the stages of works has been and remains relevant.

Backfilling plays an important role in its solution. Work out can be performed with smaller bypassed areas when deformations are reduced by backfilling.

Today, backfilling of mines of PJSC Uralkali is carried out mainly by a hydraulic method and less often mechanically.

Solid wastes from processing of potassium ores (salt wastes) and rock salt from the excavation of field workings in small amounts are used as filling material.

During hydraulic backfilling a filling massif is built by aggregation. Aggregation technology includes operations that are as follows: pulp preparation, pulp transportation, pulp holding by bulkheads and brine return.

Filling material moves from the place of pulp preparation and passes through pulp pipeline into the worked-out space. Pulp feed into the chamber is performed at one or several points along its length. The number of feed points depends on the angle of a camera, angle of array slope, length and height of achamber and required degree of filling.

During mechanical filling salt waste is delivered to backfilling site on belt conveyors.

Filling material is removed from a belt conveyor by a plow spreader at backfilling site. Then filling material is delivered to worked out space either by scraper winches or self-propelled wagons.

Most experts agree on the favorable effect of backfilling on geomechanical state around the mines [2-8]. Thus, it is noted that backfilling allows to reduce the speed of deformation of bypassed areas and magnitude of deformation of rocks and the earth's surface. As a consequence, it is recommended to use a backfilling under the urban development and important industrial facilities. At the same time, attention is paid to the fact that the influence of brines supplied with filling material on stability of interchamer bypassed areas has not been studied enough. It is impossible to support roof of excavations completely because of the gentle bedding of the ore body. There is a gap between the roof and backfilling, the size of which depends on the method of filling as well as mining and geological conditions.

A number of works notes that backfilling also reduces air leakage in worked out space, which positively affects ventilation of mines and is an efficient way to protect natural environment [9-12].

\section{Development of a software module that automate processing of surveying measurements of backfills volumes}

Filling operations at mining enterprises of Uralkali PJSC are conducted in accordance with requirements of regulatory documents [13, 14]. Their volumes for specific excavation units are regulated by technical projects and mining development plans. Monitoring of compliance with 
designed volumes backfilling is carried out by surveying service of mining enterprises through instrumental surveys. At the same time, volumes of filling work that increase annually make the solution for the challenge of automation of processing of instrumental measurements of backfilling and drawing up graphical and text report documentation relevant. To overcome this challenge the authors of the article in 2005 developed and installed at workplace of users at Silvinit OJSC mines the first version of a software module with conventional name Backfill. Details on the main functional features of that soft can be found in the work [15].

However, during the following years urgency of filling operations has increased significantly. First of all, due to frequent cases of negative impact of mining operations on the earth's surface and industrial, civil and natural objects on it, as well as discontinuity (TVZ) and water breakthrough into mines. The most significant demonstration of that impact can be represented by emergency flooding of BPKRU-1 in Berezniki in 2006, earth's surface subsidence near the railway tracks at the station of Berezniki in 2010 and appearance of a depression on the earth's surface and breakthrough of water into mines SKRU-2 in 2014.

All these facts led to strict requirements for carrying out the filling operations in the new approved regulatory documents [13, 14]. In particular, these documents increase requirements for the degree of backfill of cleaning chambers as a technological element of a development system (backfilling factor must satisfy the condition $A \geq$ $0.7)$ and as a protection effort that reduces values of maximum deflection of layers and maximum subsidence of the earth's surface $(0,5 \leq A \leq 0,7)$. Besides, a number of report forms has been significantly increased in terms of planned and actual volumes of filled underground space and volumes of not filled empty space. A special control over the percentage content of clay-salt slurries in the packing pulp (no more than $4 \%$ ) was established.

In connection with factors above mentioned, the company management has put forward new requirements to functionality of the previously created software module for processing mine survey measurements of backfills in mines.

The main requirements of those are:

- changes in an algorithm of a software module related to new requirements of regulative documents for carrying out filling operations, including the qualitative composition of pulp filling;

- implementation of the most close integration of the Zakladka software module with the forming mining and geological information system (MGIS) of Uralkali PJSC;

- filling in the automated mode of new approved reporting forms ${ }^{1}$;

- an ability to switch the module into more modern versions of additional programs such as versions of data base management system (DBMS) Oracle, Graphic visualizers, operating system, office products etc.;

- an ability to import and export data into the formats xls (Excel), dxf (AutoCad), shape-files ESRI (ArcGis), tab (MapInfo).

Consideration of above requirements during updating of the previously created Zakladka software module led to the fact that an almost new software was created, which was given the conventional name Zakladka-2. Let's consider the main features of the newly created software module and its difference from the previously created software on the following aspects: functionality, technical architecture of the software, interface solutions and reporting documentation.

Functional possibilities. Many years of experience of the Bookmark software module made it possible to reveal that individual functionalities implemented in the software are not relevant for today and can be safely abandoned. In particular, there were not much applications for abilities of the software to fill DBMS tables with initial data on backfilling mines by digitizing their cross sections using scanned images (raster) and a digitizer. After abandoning these and some other features, as well as adding new functions in the

1 The Order on Uralkali PJSC "About report forms on backfilling at the mines of Uralkali PJSC" (No. 977 from 14.06.2016). 
Zakladka-2 program module it is possible to solve the following tasks:

- processing of instrumental surveying measurements of backfills performed by mechanical and hydraulic methods, and its saving to DBMS tables of Oracle;

- calculation of the volume of backfills and the actual coefficients of filling of worked out space along the transverse and longitudinal sections of production and comparing them with design parameters both for single mines and for the sets of filled mines within the allocated zones;

- determination of the optimal design position of filling (bypass) wells in case of hydraulic filling based on the analysis of production geometry, pulp and pulp pipe characteristics and taking into account new requirements of regulatory documents as well;

- modeling the process of hydraulic backfilling on the longitudinal section of the mine taking into account bulkheads and new requirements of regulatory documents;

- graphical display of backfilling of the transverse and longitudinal sections of a mine as well as on the digital mining plan;

- creation and printing of graphical and textual standard documentation on filling and empty space in mines taking into account new requirements of normative documents.

Technical architecture of the software. The Zakladka-2 software is one of the software modules included in a software complex Automated workplace of mine surveyor (ARMmine surveyor). This software package is installed on users' work places for the automated solution of the best part of production tasks that are faced by experts of surveying service: from the local surveyor at the mine to the head of the mine survey service of Uralkali PJSC [16-20]. The modular structure of software packages allows you to equip a workplace with functionality in accordance with requests of a particular user. Software modules included in a software ARM Marksheyder with the active option "Filling work" are shown in Fig. 1.

Work of software modules is built on the basis of a client-server architecture using the TCP/IP protocol controlled by Windows operating system no lower than the seventh version. Oracle $12 \mathrm{c}$ (12.1.0.1) is used as a DBMS. At the time of the paper writing data on all software modules of various software complexes are stored in 420 linked tables.

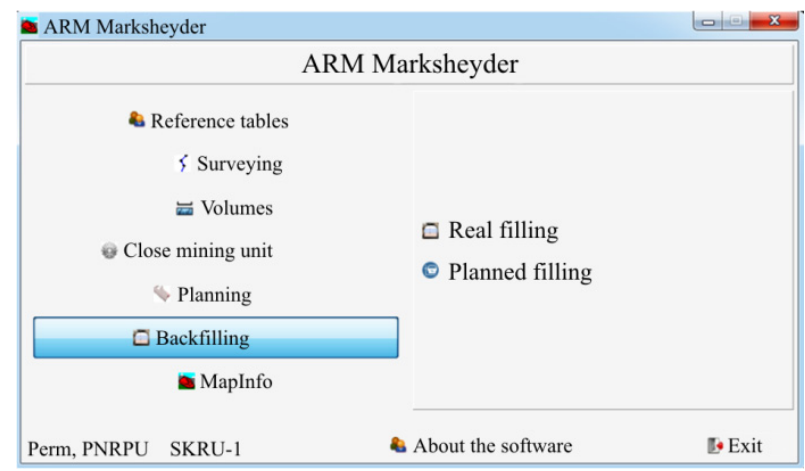

Fig. 1. The panel for selecting program modules in the ARM-mine surveyor

It should be noted that in the future, in order to reduce a price of project for the creation of DBMS of Uralkal PJSC, the possibility of switching to a freely distributed PostgreSQL (Postgres Pro Standard) is considered.

Graphical visualization is carried out on digital layers in the free geoinformation system QGIS, which supports work with vector file formats GeoJSON, shape-files ESRI, MapInfo, SDTS (Spatial Data Transfer Standard), GML (Geography Markup Language) etc., as well as with raster file formats and graphs GeoTIFF, Erdas IMG, ArcInfo ASCII Grid, JPEG, PNG etc. The rules of work with digital graphic documentation are defined in the classifier of objects of digital plans and maps for scales from 1:500 to 1:10000 developed by the authors [21].

Programming language $\mathrm{C}++$ was used to write software code modules.

Interface solutions. During development of the Zakladka-2 software module the user's wishes to keep interface solutions as in the previous version of the software were taken into account. Therefore, despite the changes made in the software, the structure of big part of the work windows has remained the same. Examples of the main information windows with changes applied in are shown in Fig. 2-4. 


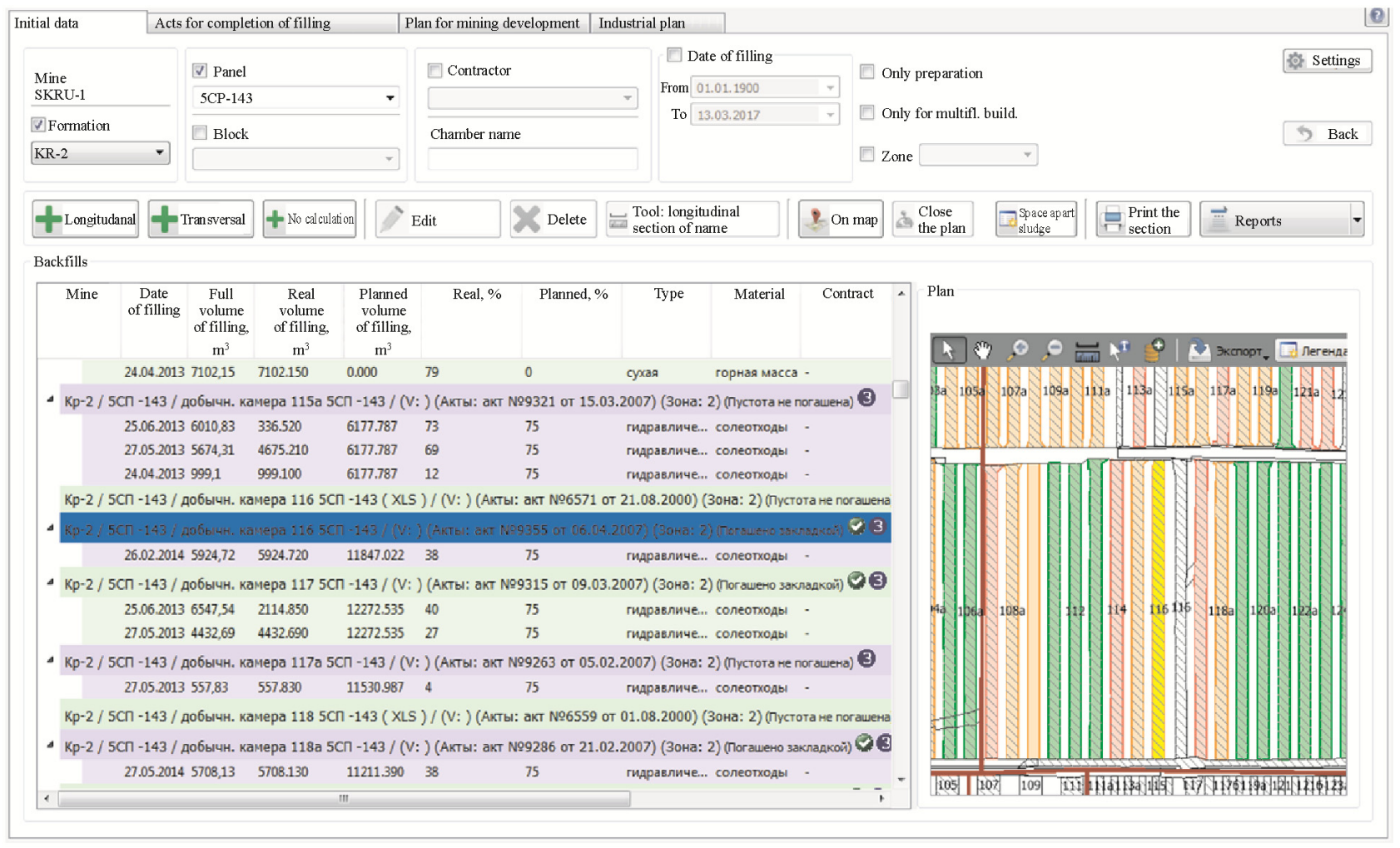

Fig. 2. The main window of the software

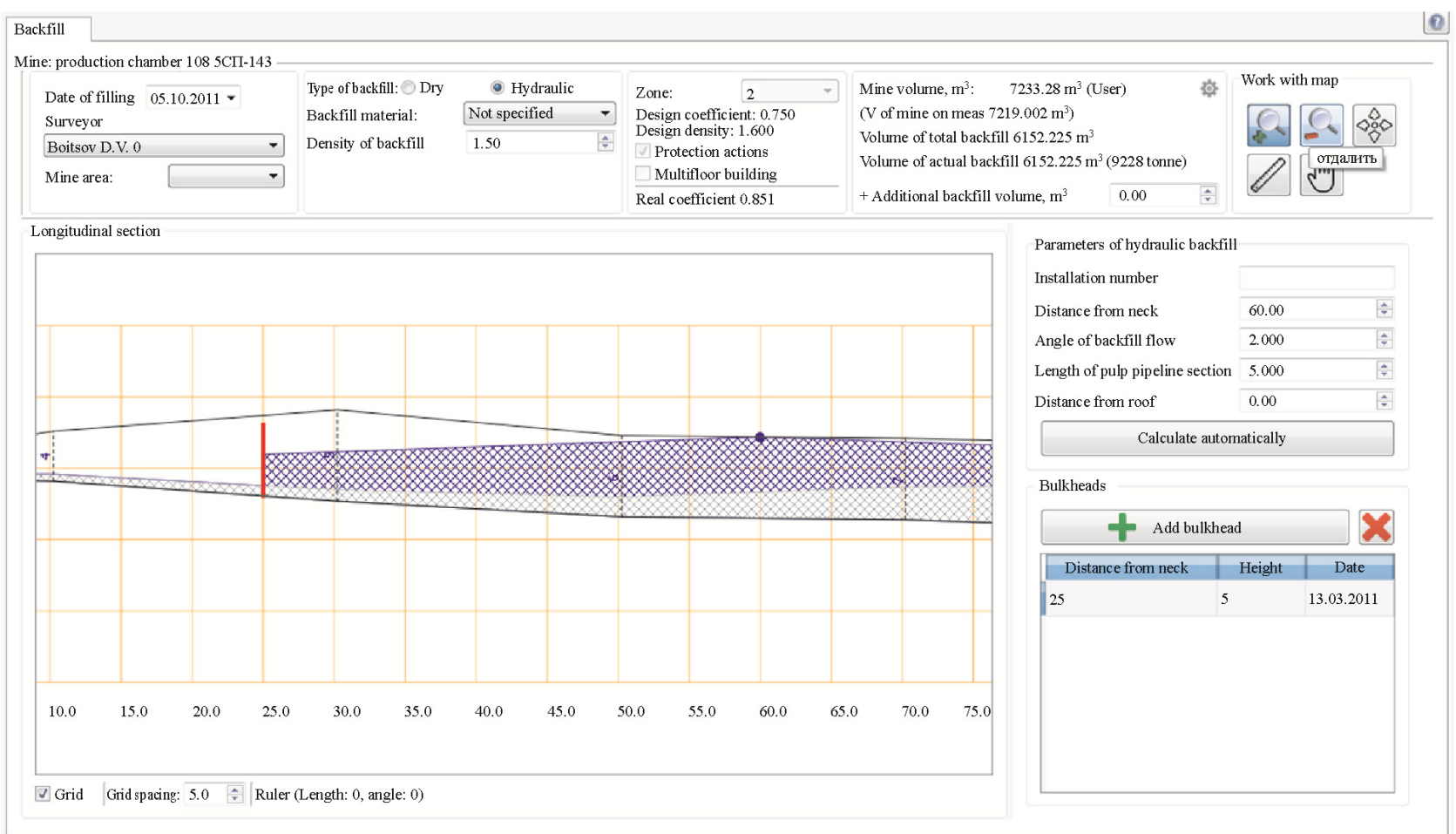

Fig. 3. The window for calculation the volume of backfills by longitudinal sections taking into account bulkheads at the different dates of surveying measurements 


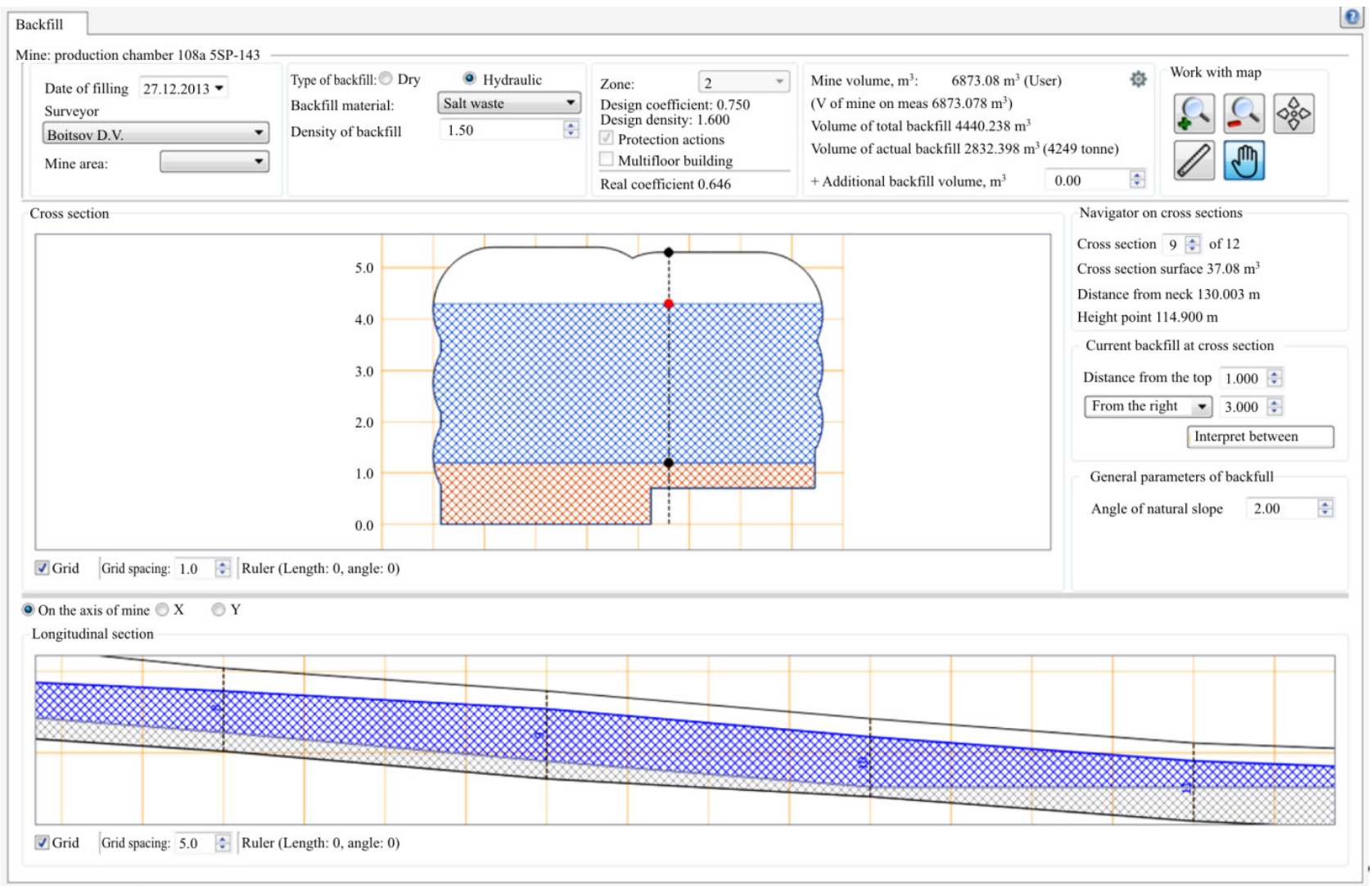

Fig. 4. The window for calculation the volume of a backfill by cross sections at different dates of surveying measurements

A detailed description of functional capabilities of the windows shown in Fig. 2-4 and other windows used in the software is given in [22].

Report documents. As it was mentioned previously, in accordance with the Order of Uralkali PJSC and in compliance with the requirements of new regulatory documents [13, 14], the list of report documents on backfilling of worked out space and underground voids has been expanded significantly. The total number of created report documents has been increased from 5 to 13 tablets. In order to perform automated compilation of such forms it was necessary to analyze availability of data in the Zakladka-2 software module on geometric parameters of mines and the amount of filling material needed in the Oracle DBMS tables for all the operating mines of Uralkali PJSC. The analysis showed that there is no necessary information only for SKRU-1 mine on excavations made in the period from 1934 to 2007. Thus, in order to compile required report documents for backfilling data on 10607 chambers was input to the tables of DBMS.

As a conclusion it has to be said that Zakladka2 software module was created taking into account its adaptation to creating mine and geological information system of Uralkali PJSC. Construction and use of mining and geological information and intellectual systems have found wide application in large mining enterprises in the United States, Germany, Australia and others [23-28]. Several mining enterprises in Russia are also working in the same direction (GMK Norilsky Nickel, Uralkali PJSC, Kolskaya GMK mining and smelting company etc.).

The authors of the article participate in development of MGIS of Uralkali PJSC directly. The system includes 21 automated work places for various mining specialists (miners, geologists, mine surveyors, geophysicists, geomechanics, environmentalists etc.) from the primary link at mines to the management of Uralkali PJSC [29-35]. 


\section{References}

1. Solov'ev V.A. et al. Vedenie gornykh rabot na rudnikakh Verkhnekamskogo kaliinogo mestorozhdeniia [Mining at the mines of the Verkhnekamsk potash deposit]. Moscow, Nedra, 1992, 467 p.

2. Borzakovskii B.A., Papulov L.M. Zakladochnye raboty na Verkhnekamskikh kaliinykh rudnikakh [Lining at the Verkhnekamsk potash mines]. Moscow, Nedra, 1994, $234 \mathrm{p}$

3. Golik V.I., Luk'ianov V.G. Obosnovanie vozmozhnosti umen'sheniia poter' $\mathrm{v}$ tselikakh za schet podpora tverdeiushchimi smesiami [Substantiation of the possibility of reducing losses in the pillars due to backing by hardening mixtures] Izvestiia Tomskogo politekhnicheskogo universiteta, 2015, no.12, pp.31-36.

4. Konstantinova S.A., Vaulin I.B. Vliianie zakladki vyrabotannogo prostranstva na napriazhenno-deformirovannoe sostoianie karnallitovykh mezhdukamernykh tselikov [Influence of a bookmark of the worked out space on the stressstrain state of carnallite interlocking pillars]. Izvestiia Tul'skogo gosudarstvennogo universiteta. Nauki o Zemle, 2012, no.1, pp.71-76.

5. Lautenbach T. Bookmark of underground cavities by means of reciprocating pumps. Gluckauf, GVSt, North Rhine-Westphalia, Herne, 2006, no.4, pp.40-44.

6. Barrett J.R., Coulthard M.A., Dight P.M. Determination of fill stability, mining with backfill. $12^{\text {th }}$ Canadian Rock Mechanics Symposium, Sudbury, Ontario, May 23-25, 1978, CIM Special vol. 19, pp.85-91.

7. Nantel J.H. Recent developments and trends in backfill practices in Canada. Proceedings of the $6^{\text {th }}$ International Symposium on Mining with Backfill, Brisbane, Australia, 14-16 April, Australasian Institute of Mining and Metallurgy, 1998, pp.11-14.

8. Bloss M.L. Evolution of cemented rock fill at mount Isa Mines Limited. Mineral Resources Engineering, 1996, vol.5, no.1, pp.23-43. DOI: 10.1142/S0950609896000042

9. Shkuratskii D.N., Rusakov M.I. Ispol'zovanie otkhodov proizvodstva kaliinykh udobrenii $\mathrm{v}$ porodnykh smesiakh dlia zakladki vyrabotannykh prostranstv [The use of wastes from the production of potash fertilizers in rock mixtures to lay waste spaces]. Izvestiia Tul'skogo gosudarstvennogo universiteta. Nauki o Zemle, 2015, no.3, pp.87-97.

10. Borzakovskii B.A., Rusakov M.I., Alymenko D.N. Otsenka effektivnosti zakladochnykh rabot na rudnikakh Verkhnekamskogo mestorozhdeniia kaliinykh solei [Evaluation of the efficiency of filling operations at the mines of the Verkhnekamskoye potassium salt deposit]. Gornyi zhurnal, 2012, no.8, pp.125-127.

11. Khakurate A.M., Vertiachikh K.S. Aspekty primeneniia zakladki $\mathrm{V}$ zarubezhnoi i otechestvennoi praktike podzemnoi razrabotki rud [Aspects of application of the bookmark in foreign and domestic practice of underground mining of ores]. Gorno-informatsionnyi analiticheskii biulleten': nauchno-tekhnicheskii zhurnal, 2002, iss.10, pp.1-5, 88-92.
12. Palarski J. The use of fly ash, tailings, rock and binding agents as consolidated backfill for coal mines. In Proc. Minefill, South African Institute of Mining and Metallurgy. Ed. H.W. Glen. Johannesburg, 1993, pp.403-408.

13. Kutovoi S.N., Kataev A.V., Efimov E.M. Avtomatizatsiia marksheiderskogo obsluzhivaniia zakladochnykh rabot na rudnikakh Verkhnekamskogo mestorozhdeniia kaliinykh solei [Automation of surveying services for laying works at the mines of the Verkhnekamsk deposit of potassium salts]. Marksheiderskii vestnik, 2008, no.4, pp.22-27.

14. Kutovoi S.N., Kruglov Iu.V. Avtomatizatsiia planirovaniia gornykh rabot na baze tsifrovykh marksheiderskikh planov [Automation of mining planning based on digital surveying plans]. Nauka proizvodstvu, 2002, no.4, pp.5-7.

15. Kataev A.V., Kutovoi S.N., Telitsyn A.V., Nesterov E.V., Gilev M.V. Avtomatizirovannoe rabochee mesto marksheidera na baze tsifrovykh planov gornykh rabot [Automated workplace surveyor based on digital mining plans]. Marksheiderskii vestnik, 2003, no.2, pp.28-31.

16. Kataev A.V., Kutovoi S.N, Kutyrev V.F. Opyt sozdaniia GIS geologo-marksheiderskoi sluzhby [The experience of creating a GIS geological survey service]. Geoprofi, 2004, no.6, pp.5-7.

17. Kataev A.V., Kutovoi S.N., Telitsyn A.V., Nesterov E.V. Avtomatizatsiia marksheiderskikh vychislenii i ikh graficheskogo oformleniia na tsifrovykh planakh gornykh rabot [Automation of mine surveying and their graphic design on digital mining plans]. Nauka proizvodstvu, 2003, no.10, pp.24-31.

18. Kataev A.V., Kutovoi S.N., Efimov E.M., Gilev M.V. Ekspluatatsionnye poteri i razubozhivanie $\mathrm{V}$ informatsionnoi sisteme OAO «Sil'vinit» [The operational losses and dilution in the information system of OJSC "Silvinit"]. Marksheiderskii vestnik, 2009, no.3, pp.36-40.

19. Kataev A.V., Kutovoi S.N., Kiselev A.O., Kislukhina S.A., Gilev M.V. Metodika sozdaniia tsifrovykh marksheiderskikh planov dlia rudnikov Verkhnekamskogo mestorozhdeniia kaliinykh solei [Method for creating digital surveying plans for the mines of the Verkhnekamsk potassium salt deposit]. Problemy formirovaniia $i$ kompleksnogo osvoeniia mestorozhdenii solei. VI solevoe soveshchanie: materialy mezhdunarodnoi konferentsii. Solikamsk, 2000, pp.82-84.

20. Litvinov A.G. Tekhnologiia razrabotki intellektual'nykh geoinformatsionnykh sistem gorno-promyshlennykh kompleksov [The technology of development of intellectual geoinformation systems of mining complexes]. Doctor's degree dissertation. Moscow, 2006, 152 p.

21. Waterman D.A. A guide to expert systems. Reading, MA: Addison-Wesley, 1986, 419 p.

22. Jain A.K., Jianchang Mao, Mohiuddin K.M. Artificial neural networks: a tutorial. Computer, 1996, vol.29, no.3, pp. 31-34, available at: http://www.cogsci. 
ucsd.edu/ ajyu/Teaching/Cogs202_sp12/Readings/jain_an n96.pdf (accessed: 12 January 2017).

23. Barnes M.P. Drill-hole interpolation: estimating mineral inventory. Open pit Mine Planning and Design. New York, 1979, pp.65-80.

24. Mitchell T.M. Version spaces: an approach to concept learning. Ph.D. thesis, STAN-CS-78-711, Stanford University, Palo Alto, CA, 1978.

25. Doyle J. Truth maintenance systems for problem solving. Proceedings of the Fifth International Joint Conference on Artificial Intelligence (IJCAI-77), Cambridge, Massachusetts, 1977, p. 247.

26. Kataev A.V., Kutovoi S.N. Razrabotka kontseptsii informatsionnoi sistemy OAO "Sil'vinit" [Development of the concept of the information system of OJSC Silvinit]. Marksheiderskii vestnik, 2003, no.2, pp.21-25.

27. Kataev A.V., Kutovoi S.N., Efimov E.M., Meister D.A. Sozdanie gorno-geologicheskoi informatsionnoi sistemy gornykh predpriiatii [Creation of a mining and geological information system of mining enterprises]. Rudnik budushchego, 2014, no.3-4, pp.38-49.

28. Kataev A.V., Kutovoi S.N., Efimov E.M., Meister D.A. Sozdanie gorno-geologicheskoi informatsionnoi sistemy PAO "Uralkalii" [Creation of the mining and geological information system of PJSC Uralkali]. Issledovano $v$ Rossii, 2014, pp.26-31, available at: http://rud.igduran.ru/ edition/9 (accessed 12 January 2017).
29. Kataev A.V., Kutovoi S.N. Razrabotka modeli geologicheskoi sredy dlia rudnikov Verkhnekamskogo mestorozhdeniia kaliinykh solei [Development of a model of the geological environment for the mines of the Verkhnekamsk deposit of potassium salts]. Marksheiderskii vestnik, 2003, no.2, pp.25-27.

30. Kataev A.V., Kutovoi S.N. Reshenie zadach gornoi geomekhaniki na baze geologicheskoi modeli massiva [Solving the problems of mining geomechanics based on the geological model of the massif]. Sovremennye geomekhanicheskie metody $v$ gornoi promyshlennosti $i$ podzemnom grazhdanskom $i$ tunnel'nom stroitel'stve: materialy mezhdunarodnoi geomekhanicheskoi konferentsii. Nesebyr, Bolgariia, 2003, pp.19-22.

31. Kataev A.V., Kutovoi S.N., Kiselev A.O., Kruglov Iu.V. Vnedrenie GIS-tekhnologii na kaliinykh rudnikakh Urala [Introduction of GIS-technologies at the potash mines of the Urals]. Izvestiia vuz(ov). Gornyi zhurnal, 2003, no.2, pp.111-116.

32. Kutovoi S.N. Raschet prognoznykh osedanii zemnoi poverkhnosti $\mathrm{s}$ ispol'zovaniem integratsionnykh setok na primere otrabotki Verkhnekamskogo mestorozhdeniia kaliinykh solei [Calculation of predicted subsidence of the earth's surface using integration grids for the example of working off the Verkhnekamsk potassium salt deposit]. Izvestiia vuz(ov). Gornyi zhurnal, 2012, no.7, pp.37-44.

\section{Библиографический список}

1. Ведение горных работ на рудниках Верхнекамского калийного месторождения: метод. руководство / В.А. Соловьев [и др.]; под общ. ред. В.А. Соловьева. - М.: Недра, 1992. - 467 с.

2. Борзаковский Б.А., Папулов Л.М. Закладочные работы на Верхнекамских калийных рудниках. - М.: Недра, 1994. - 234 с.

3. Голик В.И., Лукьянов В.Г. Обоснование возможности уменьшения потерь в целиках за счет подпора твердеющими смесями // Известия Томского политехнического университета. - 2015. - № 12. С. 31-36.

4. Константинова С.А., Ваулин И.Б. Влияние закладки выработанного пространства на напряженнодеформированное состояние карналлитовых междукамерных целиков // Изв. Тульск. гос. ун-та. Науки о Земле. - 2012. - № 1. - С. 71-76.

5. Lautenbach T. Bookmark of underground cavities by means of reciprocating pumps // Gluckauf. - 2006. № 4. - P. 40-44.

6. Barrett J.R., Coulthard M.A., Dight P.M. Determination of fill STABILITY, mining with backfill // $12^{\text {th }}$ Canadian Rock Mechanics Symposium. - 1978. Special vol. 19. - P. 85-91.

7. Nantel J.H. Recent developments and trends in backfill practices in Canada // Proceedings of the $6^{\text {th }}$ International Symposium on Mining with Backfill / Australasian Institute of Mining and Metallurgy. Brisbane, 1998. - P. 11-14.

8. Bloss M.L. Evolution of cemented rock fill at mount Isa Mines Limited // Mineral Resources Engineering. - 1996. - Vol. 5, № 1. - P. 23-43. DOI: 10.1142/S0950609896000042

9. Шкуратский Д.Н., Русаков М.И. Использование отходов производства калийных удобрений в породных смесях для закладки выработанных пространств // Изв. Тульск. гос. ун-та. Науки о Земле. - 2015. - № 3. - С. 87-97.

10. Борзаковский Б.А., Русаков М.И., Алыменко Д.Н. Оценка эффективности закладочных работ на рудниках Верхнекамского месторождения калийных солей // Горный журнал. - 2012. - № 8. - С. 125-127.

11. Хакурате А.М., Вертячих К.С. Аспекты применения закладки в зарубежной и отечественной практике подземной разработки руд // Горноинформационный аналитический бюллетень: научнотехнический журнал. - 2002. - Вып. 10. - С. 1-5, 88-92.

12. Palarski J. The use of fly ash, tailings, rock and binding agents as consolidated backfill for coal mines // In Proc. Minefill 93 / Ed. H.W. Glen. - Johannesburg: South African Institute of Mining and Metallurgy, 1993. P. 403-408. 
13. Указания по защите рудников от затопления и охране подрабатываемых объектов в условиях Верхнекамского месторождения калийных солей / ГИ УрО РАН. - СПб., 2014. - 126 с.

14. Методические рекомендации к «Указаниям по защите рудников от затопления и охране подрабатываемых объектов на Верхнекамском месторождении калийномагниевых солей» / ГИ УрО РАН. - СПб., 2014. - 65 с.

15. Кутовой С.Н., Катаев А.В., Ефимов Е.М. Автоматизация маркшейдерского обслуживания закладочных работ на рудниках Верхнекамского месторождения калийных солей // Маркшейдерский вестник. - 2008. - № 4. - С. 22-27.

16. Кутовой С.Н., Круглов Ю.В. Автоматизация планирования горных работ на базе цифровых маркшейдерских планов // Наука производству. - 2002. - № 4. - С. 5-7.

17. Автоматизированное рабочее место маркшейдера на базе цифровых планов горных работ / А.В. Катаев, С.Н. Кутовой, А.В. Телицын, Е.В. Нестеров, М.В. Гилев // Маркшейдерский вестник. - 2003. - № 2. - С. 28-31.

18. Катаев А.В., Кутовой С.Н., Кутырев В.Ф. Опыт создания ГИС геолого-маркшейдерской службы // Геопрофи. - 2004. - № 6. - С. 5-7.

19. Автоматизация маркшейдерских вычислений и их графического оформления на цифровых планах горных работ / А.В. Катаев, С.Н. Кутовой, А.В. Телицын, Е.В. Нестеров // Наука производству. 2003. - № 10. - C. 24-31.

20. Эксплуатационные потери и разубоживание в информационной системе ОАО «Сильвинит» / А.В. Катаев, С.Н. Кутовой, Е.М. Ефимов, М.В. Гилев // Маркшейдерский вестник. - 2009. - № 3. - С. 36-40.

21. Методика создания цифровых маркшейдерских планов для рудников Верхнекамского месторождения калийных солей / А.В. Катаев, С.Н. Кутовой, А.О. Киселев, С.А. Кислухина, М.В. Гилев // Проблемы формирования и комплексного освоения месторождений солей: VI солевое совещание: материалы междунар. конф. - Соликамск, 2000. - С. 82-84.

22. Развитие рабочего места участкового маркшейдера, рабочего места маркшейдера отдела капитальных маркшейдерских работ, поддержка и развитие программных модулей обеспечения геомеханических расчетов: отчет о работе. - Пермь: Изд-во Перм. нац. исслед. политехн. ун-та, 2016. - 69 с.

23. Литвинов А.Г. Технология разработки интеллектуальных геоинформационных систем горнопромышленных комплексов: дис. ... д-ра техн. наук. M., 2006. - 152 c.
24. Waterman D.A. A guide to expert systems. Reading, MA: Addison-Wesley, 1986. - 419 p.

25. Anil K.J., Jianchang Mao, Mohiuddin K.M. Artificial neural networks: a tutorial [Электронный pecypc] // Computer. - 1996. - Vol. 29, № 3. - P. 31-34. - URL: http:/www.cogsci.ucsd.edu/ ajyu/Teaching/Cogs202_sp12/Re adings/jain_ann96.pdf (дата обращения: 12.01.2017).

26. Barnes M.P. Drill-hole interpolation: estimating mineral inventory // Open pit Mine Planning and Design. New York, 1979. - P. 65-80.

27. Mitchell T.M. Version spaces: an approach to concept learning. Ph.D. thesis, STAN-CS-78-711. Stanford University, Palo Alto, CA, 1978.

28. Doyle J. Truth maintenance systems for problem solving // Proceedings of the Fifth International Joint Conference on Artificial Intelligence (IJCAI-77). Cambridge, Massachusetts, 1977. - P. 247.

29. Катаев А.В., Кутовой С.Н. Разработка концепции информационной системы ОАО «Сильвинит» // Маркшейдерский вестник. - 2003. - № 2. - С. 21-25.

30. Создание горно-геологической информационной системы горных предприятий / А.В. Катаев, С.Н. Кутовой, Е.М. Ефимов, Д.А. Мейстер // Рудник будущего. - 2014. № 3 - 4. - С. $38-49$.

31. Создание горно-геологической информационной системы ПАО «Уралкалий» [Электронный ресурс] / А.В. Катаев, С.Н. Кутовой, Е.М. Ефимов, Д.А. Мейстер // Исследовано в России. - 2014. - С. 26-31. - URL: http://trud.igduran.ru/ edition/9 (дата обращения: 12.01.2017).

32. Катаев А.В., Кутовой С.Н. Разработка модели геологической среды для рудников Верхнекамского месторождения калийных солей // Маркшейдерский вестник. - 2003. - № 2. - С. 25-27.

33. Катаев А.В., Кутовой С.Н. Решение задач горной геомеханики на базе геологической модели массива // Современные геомеханические методы в горной промышленности и подземном гражданском и туннельном строительстве: материалы междунар. геомеханической конф. - Несебыр, Болгария, 2003. C. 19-22.

34. Внедрение ГИС-технологий на калийных рудниках Урала / А.В. Катаев, С.Н. Кутовой, А.О. Киселев, Ю.В. Круглов // Известия вуз(ов). Горный журнал. - 2003. - № 2. - С. 111-116.

35. Кутовой С.Н. Расчет прогнозных оседаний земной поверхности с использованием интеграционных сеток на примере отработки Верхнекамского месторождения калийных солей // Известия вуз(ов). Горный журнал. 2012. - № 7. - С. 37-44.

Please cite this article in English as:

Kutovoi S.N., Kataev A.V., Vasenin D.A., Efimov E.M. Work experience on automation of processing of survey measurements of backfill of mines of Uralkali PJSC. Perm Journal of Petroleum and Mining Engineering, 2017, vol.16, no.2, pp.174-182. DOI: 10.15593/2224-9923/2017.2.8

Просьба ссылаться на эту статью в русскоязычных источниках следующим образом:

Опыт работ по автоматизации обработки маркшейдерских замеров закладки выработанного пространства на рудниках ПАО «Уралкалий» / С.Н. Кутовой, А.В. Катаев, Д.А. Васенин, Е.М. Ефимов // Вестник Пермского национального исследовательского политехнического университета. Геология. Нефтегазовое и горное дело. - 2017. - Т.16, №2. - С.174-182. DOI: $10.15593 / 2224-9923 / 2017.2 .8$ 